\begin{tabular}{llll}
\hline Estudios de Economía Aplicada & Vol. 29-3 $2011 \quad$ PÁgs. 679-692 \\
\hline
\end{tabular}

\title{
What Tourism Economists Do. Their Contribution to Understanding Tourism*
}

\section{STEPHEN WANHILL}

\author{
Kemmy Business School, UNIVERSITY OF LIMERICK, IRELAND. E-mail: \\ stephen@wanhill.force9.co.uk
}

\begin{abstract}
The journal Tourism Economics was established in 1995. This article is a statistical report on the topics examined by tourism economists from the inception of the journal until now. The tables and the accompanying text are meant as a guide to research and not an overview of tourism economics as a subject, for which there are several textbooks available. To maintain a sense of objectivity, only articles that were awarded 'best paper' recognition are cited, so in the main the discussion focuses on the popularity of research themes and areas where further investigation would appear worthwhile. It is noted that in many cases a major obstacle has been the availability of data to progress the applied nature of the discipline.
\end{abstract}

Keywords: Tourism, Economics, Research, Topics.

\section{Qué hacen los economistas del turismo. Su contribución a la comprensión del Turismo}

\begin{abstract}
RESUMEN
La revista Tourism Economics se fundó en 1995. Este artículo es un informe estadístico sobre los temas tratados en la revista desde sus comienzos hasta la actualidad por los economistas del turismo. El texto y las tablas que se presentan se han concebido a modo de guía para la investigación y no como un repaso sobre la economía del turismo como tema para lo que pueden encontrarse varios libros de texto disponibles. Para mantener un sentido de objetividad, sólo se han citado los artículos que han sido distinguidos con la mención de "best paper" en la revista así que la discusión se centra principalmente en la popularidad de los temas de investigación y las áreas donde aparecerán probablemente las próximas investigaciones alrededor del mundo. Es remarcable ver que para avanzar en la naturaleza aplicada de la disciplina, el mayor obstáculo ha sido en muchos casos, la falta de disponibilidad de datos.
\end{abstract}

Palabras clave: Turismo, economía, temas de investigación.

JEL Classification: L80, M10

\footnotetext{
* Thanks are due to John Edmondson, the publisher of Tourism Economics for his kind assistance.
}

Artículo disponible en versión electrónica en la página www.revista-eea.net, ref. ə-29311 


\section{INTRODUCTION}

The focus of this article concerns submissions to the journal Tourism Economics from 1995 to 2011. It is not a treatise on the scope of tourism economics, for which ample coverage may be found in two excellent texts by Dwyer et al (2010) and Stabler et al (2010), but rather a statistical report on the range and frequency of papers sent to the journal, so as to illustrate what stimulates the curiosity of researchers in the field. It is hoped that this will be of general interest to readers of this special issue, while at the same time indicating areas of research worthy of further investigation.

Table 1

Tourism Economics' Submissions 1995-2011

\begin{tabular}{|l|c|}
\hline \multicolumn{1}{|c|}{ SUBJECT } & $\mathbf{1 9 9 5 - 2 0 1 1}$ \\
\hline Data Analysis and Statistical Theory & $3 \%$ \\
\hline Demand Models & $19 \%$ \\
\hline Markets & $5 \%$ \\
\hline Supply Issues & $10 \%$ \\
\hline Tourism Industry & $26 \%$ \\
\hline Tourism Governance & $15 \%$ \\
\hline Macro Assessment & $22 \%$ \\
\hline
\end{tabular}

Source: Own elaboration.

Table 1 presents the cumulative results to 2011 by broad topic area. It will be appreciated that in an applied subject there is commonly a variety of aspects dealt with in any one paper, so the listing in Table 1 classifies papers according to their main contribution.

The compilations shown in Table 1 refer to general submissions by individuals, rather than collectives in the form of special issues of Tourism Economics. To date there have been fifteen anthologies as indicated in Table 2, many being drawn from international conferences on the subject, notably the International Association for Tourism Economics (IATE). Researchers find it beneficial to have such collections as they provide rapid access to what is being undertaken in a specific area of the discipline. 
Table 2

Special Issues of Tourism Economics

March 1999: Seasonality in tourism - understanding the challenges (Ed. T. Baum)

December 1999: Measurement of the economic impact of tourism - WTO's EnzoPaci World Conference at Nice (Eds. P. Shackleford and A.M. Verdugo)

June 2000: Tourism safety and security (Ed. A. Steene)

September 2002: Measuring the economic impact of tourism (Ed. T. Var)

December 2003: Tourism modelling and policy (Eds. M.T. Sinclair and R. Spurr)

March 2005: Tourism competitiveness (Eds. P. Pashardes and M.T. Sinclair)

December 2005: Advances in tourism economics (Eds. C.P. Barros and Á. Matias)

June 2006: Current issues in Australian tourism (Ed. S. Divisekera)

December 2007: Island tourism economies and sustainable development (Eds. M. Sahli, L. Dwyer, M.-A. Maupertuis and J.-J. Nowak)

March 2008 Recent advances in tourism research. Part 1: International tourism and competitiveness in the tourism industry. Part 2: Island tourism - facts and challenges (Eds. C. P. Barros, Á. Matias and C. M. Santos)

December 2008 Economic modelling of tourism (Ed. A. Blake)

September 2009 Modern approaches in tourism economics and econometrics (Eds. E. Aguiló, J. Lozano, V. Ramos and J. Rey-Maquieira)

March 2010 The economics of tourism - new directions (Eds. A. Blake and I. Cortés-Jímenez)

June 2010 New advances in tourism economics (Eds. C. P. Barros and Á. Matias)

June 2011 Developments in the field of tourism economics (Eds. N. Kulendran, J. ReyMaquieira and M. Saayman)

Source: Own elaboration.

The remainder of this report will be taken up with further statistical breakdowns of the main subjects indicated in Table 1. Given the volume of papers presented to Tourism Economics, it would be invidious to cite any particular authors, save when the article has been universally acknowledged in the journal's best paper category. The latter is currently named in memory of Professor Thea Sinclair who was tragically killed in a riding accident some years ago. It was generally agreed by colleagues that this would be a fitting mark of respect for her contribution to our field of study. For the benefit of researchers the list of winning articles is shown in Table 3. 
Table 3

The Thea Sinclair Award for Journal Article Excellence

Dayuan Xue, Averil Cook and Clem Tisdell, 'Biodiversity and the tourism value of Changbai Mountain Biosphere Reserve, China: a Travel Cost approach', Vol 6, No 4, December 2000, pp 335-357.

Lindsay W. Turner and Stephen F. Witt, 'Factors influencing the demand for international tourism: tourism demand analysis using structural equation modelling', Vol 7, No 1, March 2001, pp 21-38.

J. Randall Brown, Aviad A. Israeli and Abraham Mehrez, 'Modelling a decision maker's preferences with different assumptions about the preference structure: theory development and initial applications for tourism and hospitality management', Vol 8, No 1, March 2002, pp $39-57$.

J.M. Espinet, M. Saez, G. Coenders and M. Fluvià, 'Effect on prices of the attributes of holiday hotels: a hedonic prices approach', Vol 9. No 2, June 2003, pp 165-177.

Stephen F. Witt, Haiyan Song and Stephen Wanhill, 'Forecasting tourism-generated employment: the case of Denmark', Vol 10, No 2, June 2004, pp 167-176.

Pedro M.D.C.B. Gouveia and Paulo M.M. Rodrigues, 'Dating and synchronizing tourism growth cycles', Vol 11, No 4, December 2005, pp 501-515.

Yoav Wachsman, 'Strategic interactions among firms in tourism destinations', Vol 12, No 4, December 2006, pp 531-541.

Yoel Mansfeld and Onn Winckler, 'The tourism industry as an alternative for the GCC oil-based rentier economies', Vol 13, No 3, September 2007, pp 333-360.

Juan L. Eugenio-Martin, Noelia Martín-Morales and M. Thea Sinclair, 'The role of economic development in tourism demand', Vol 14, No 4, December 2008, pp 673-690.

Adam Blake, 'The dynamics of tourism's economic impact', Vol 15, No 3, September 2009, pp 615-628.

Source: Own elaboration.

\section{DATA ANALYSIS AND STATISTICAL THEORY}

Although most people in developed economies are employed in services, economic textbooks still focus on the production of commodities and national income statistics commonly give little account of the service sector. Until the advent of statistical directives by international agencies such as Eurostat and OECD, and more recently UNWTO's Tourism Satellite Accounts (TSAs), most tourism statistics have been the by-product of gathering information for other purposes: balance of payments, migration, transport, employment and the registration of accommodation. Politically tourism is often seen as just a 'quick fix' for city and rural regeneration questions, so there was no need to spend too much effort on understanding it. This has left tourism researchers, particularly at the local level, having to collect their own data and hence Tourism Economics 
has had papers dealing with sampling issues of on-site and household surveys. The split between the latter and TSAs is shown in Table 4 .

Table 4

Data Analysis and Statistical Theory

\begin{tabular}{|l|c|}
\hline \multicolumn{1}{|c|}{ SUBJECT } & 1995-2011 \\
\hline Sampling and Statistical Theory & $58 \%$ \\
\hline Tourism Satellite Accounts & $42 \%$ \\
\hline
\end{tabular}

Source: Own elaboration.

TSAs have been a boon in identifying what national statistical offices need to collect to understand the tourism phenomenon, but governments have been somewhat reticent in committing themselves to the effort required, though the welcome news is that matters are improving all the time. The TSA structure (UNWTO, 1999) provides an internationally recognised standard for assessing the impact of tourism production and its links across different sectors. It incorporates ten tables as follows:

$1-4$ Tourism Consumption: inbound, outbound and domestic;

5 Tourism Production: according to characteristic industries;

6 Demand and Supply: a matrix that matches tourism demand to tourism supply by the components of tourism expenditure;

7 Employment;

8 Gross Fixed Capital Formation;

9 Public Consumption: the activities of government at various levels in support of tourism;

10 Tourism Indicators: non-monetary indicators of demand and supply, such as the volume of tourist trips, the number of accommodation establishments and so on.

Early analysis of tourism was occupied in a debate about the nature and scope of the tourism industry, but TSAs have served to disperse this by establishing a statistical platform, as well as being able to link the structure to impact assessment models. Relating TSAs to models makes them useful as a guide for policy decisions. Recently authors have been more specific in using TSAs to understand the impact of particular tourist activities, such as yachting, cruising and cultural trips. 


\section{DEMAND MODELS}

Given that tourism economists are better served with published demand data and there is pressure on tourist authorities to encourage demand, it is not surprising that researchers have done much to exercise their intellectual talents in this area, as indicated in Table 1. A breakdown of demand papers is presented in Table 5.

Table 5

Demand Models

\begin{tabular}{|l|c|}
\hline \multicolumn{1}{|c|}{ SUBJECT } & $\mathbf{1 9 9 5 - 2 0 1 1}$ \\
\hline Typologies & $10 \%$ \\
\hline Time Series & $20 \%$ \\
\hline Econometric & $59 \%$ \\
\hline Seasonality and Spatial Aspects & $11 \%$ \\
\hline
\end{tabular}

Source: Own elaboration.

Typology studies sent to the journal were dealing with specific purpose of visit characteristics, connecting economic aspects to the marketing literature. The application of time series models is now fairly routine and they have a good track record in producing seasonal forecasts by month, but what is concerning researchers is the disappointing performance of more complicated econometric forecasts, even against the most simple of time series extrapolations. While the availability of data is one problem, it has been noticed that fluctuations in the data are not internally consistent, giving rise to unreliable model estimation. There is case to be made of techniques overtaking data quality. A recurring problem in single-equation estimation has been the airfare variable. To cope with these issues, researchers have introduced what are called 'error correction models' to produce more stable long run relationships for forecasting purposes. This practice does seem to have gone some way to resolving the matter and more recent work has been with dynamic models and time varying parameters in the equations, to allow for the fact that the elasticities are likely to be influenced by government policies towards tourism and changes in fashion and tastes. There is a view that models incorporating seasonal effects are of more value in setting the tourism policy agenda.

In the main econometric models have been single equation reduced forms from multi-stage budgeting processes, derived from a separable utility structure, but researchers have investigated traditional consumer behaviour using Almost Ideal Demand Systems (AIDS) to identify all the cross-price effects between spending on tourism and other goods. At the very least demand analysis today 
should be subdivided by different markets segments and policy relevance examined. By way of contrast, spatial aspects have seen the planners' gravity model come into play which has resonance in the travel-cost method of evaluating demand for natural resources, as identified later in this article.

\section{MARKETS}

Two areas of study standout under this heading: they are competition and price. The distribution of papers is shown in Table 6. The journal has not had many papers specifically targeting competition though, as can be seen in Table 2 , a special issue has been devoted to this topic. There is a considerable interest in competition between destinations and the strengths here, in such an applied subject, have been the authors' abilities to incorporate the managerial aspects of competition in terms of marketing management and strategy. As is to be expected, the availability of data has been a hindrance in deriving more applied micro studies in tourism.

Table 6

Markets

\begin{tabular}{|l|c|}
\hline \multicolumn{1}{|c|}{ SUBJECT } & $\mathbf{1 9 9 5 - 2 0 1 1}$ \\
\hline Competition & $32 \%$ \\
\hline Price & $68 \%$ \\
\hline
\end{tabular}

Source: Own elaboration.

At the firm level, the structure is generally one of large 'aristocratic' businesses and a long tail of small enterprises. The former operate in markets which are contestable (Baumol et al, 1982), where the real threat of competition has validity in price setting. Lack of or limited economies of scale, difficulties to innovate or internalise the benefits of innovation, make firms vulnerable to major market changes, which has impacts such as a high turnover of businesses, frequent excess supply and so forth. The aristocratic firms still display monopolistic and oligopolistic features of market power through non-competitive price and supply behaviour, for example, limit-pricing and price leadership.

Apart from the traditional pricing models of economic theory, many authors have an interest in 'hedonistic' pricing, the foundations of which lie in Lancaster's (1966) paper basing consumer theory on the multiple attributes of goods and services. The journal has had a range of papers dealing with pricing in accommodation services, airlines, attractions and tour operators, including research on price stability. More recently, game theory, notably the Stackelberg 
strategy (Martin, 1993), has been used to look at pricing between suppliers and their agents in a duopoly setting.

\section{SUPPLY ISSUES}

This section covers general aspects of supply from the structure of the tourism industry to the impact of information and communication technologies (ICT). The spread of papers is shown in Table 7. Under the heading industrial structure, there have been several papers complementing the traditional industrial economics approach to describe and explain the characteristics of tourism markets through the causal linkages of the structure, conduct and performance paradigm (SCP), especially the travel trade. Current interest has been in small firms and the development of tourism clusters.

Table 7

Supply Issues

\begin{tabular}{|l|c|}
\hline \multicolumn{1}{|c|}{ SUBJECT } & $\mathbf{1 9 9 5 - 2 0 1 1}$ \\
\hline Industrial Structure & $23 \%$ \\
\hline Economic Efficiency & $21 \%$ \\
\hline Employment and Earnings & $26 \%$ \\
\hline Entrepreneurship and Management & $16 \%$ \\
\hline Information and Communication Technologies & $14 \%$ \\
\hline
\end{tabular}

Source: Own elaboration.

Aspects of efficiency have to do with productivity at the managerial level, whereby the concept is divided into that which is allocative and that which is technical, in order to maximise outputs for a given set of inputs, maximise revenue or profits or minimise costs. The principle analytical techniques are data envelopment analysis (DEA), after Charnes et al (1978), and stochastic cost frontier models, extending Farrel's (1957) seminal paper. Obtaining robust data are the key to demonstrating the power of current algorithms, and many papers have appeared in the tourism literature based on hotel data from Taiwan.

The coverage of labour issues in the journal extends from employee empowerment and quality, to structural changes in employment and impacts at the macro-level, as well as wage issues and the distribution of income from employment. On the other hand, there are fewer articles dealing with managerial economics. Treatment of the latter concerns management structures and decision-making, entrepreneurship, and innovation, thereby linking back to matters of efficiency and competitiveness. 
ICT has radically changed the shape of tourism through the cost of booking online versus traditional travel trade practice. Thus papers in this category have been helpful in keeping readers up to date with trends. The influence of ICT on consumers has been identified in examining travel groups that have the potential to transform how the airline industry delivers products and services. There is no doubt that ICT will continue to change consumer behaviour and therefore reshape the travel trade in terms of competitiveness, efficiency, innovation and productivity.

\section{TOURISM INDUSTRY}

Papers sent to Tourism Economics have covered a whole range of industry categories as illustrated in Table 8. Visitor attractions have proved to be the most popular subject area, especially man-made attractions and events. About one-half of the latter group has to do with events, their operation, management and effects on the community. For natural and recreational attractions considerable interest has been shown in their operations, as well as their valuation at large, thus joining with governance topics through determining users' willingness to pay(WTP) for public provision.

Table 8

Tourism Industry

\begin{tabular}{|l|c|}
\hline \multicolumn{1}{|c|}{ SUBJECT } & $\mathbf{1 9 9 5 - 2 0 1 1}$ \\
\hline Accommodation & $15 \%$ \\
\hline Restaurants & $4 \%$ \\
\hline Transport & $18 \%$ \\
\hline Travel Trade & $6 \%$ \\
\hline Man-Made Attractions and Events & $28 \%$ \\
\hline Natural/Recreational Attractions & $15 \%$ \\
\hline Finance & $14 \%$ \\
\hline
\end{tabular}

Source: Own elaboration.

The hospitality side of tourism is dominated by articles to do with hotel economics, with some papers on restaurants. There is not much coverage of other accommodation services: lack of published data has much to do with this.

Within the transport heading, the major emphasis is on airline economics, for the most part deregulation and the rise of low cost airlines. The increasing popularity of cruising has seen a growing amount of research on this theme, a holiday mode which combines both transport and floating resort. 
Treatment of the travel trade has focussed largely on the role of tour operators and how ICT is creating virtual intermediaries and encouraging mergers. The retail travel agency is seen to be re-inventing itself through offering bespoke services, although the long term survival of single traders is continually being questioned.

Papers on finance have ranged from managerial accounting, looking at leverage and yield, to portfolio analysis to assess risk with the capital asset pricing model (CAPM). At a more macro level the journal has had submissions looking at hospitality stock returns, commonly in the US market.

\section{TOURISM GOVERNANCE}

This heading is used as an over-arching portmanteau for tourism issues that are, in the main, concerned with the role of state provision. The subject areas are indentified in Table 9 in which public sector economics looks at the traditional analysis of public goods, above all the environment. This is turn has been allied by researchers to detailed case examples of resource management and evaluation using travel cost and contingent valuation approaches so as to construct demand curves for determining relevant benefits.

Table 9

Tourism Governance

\begin{tabular}{|l|c|}
\hline \multicolumn{1}{|c|}{ SUBJECT } & $\mathbf{1 9 9 5 - 2 0 1 1}$ \\
\hline Public Sector Economics & $10 \%$ \\
\hline Taxation & $8 \%$ \\
\hline Organisation of Tourism & $7 \%$ \\
\hline Tourism Marketing and Policy & $33 \%$ \\
\hline Terrorism/Crisis Management & $9 \%$ \\
\hline Resource Management and Evaluation & $33 \%$ \\
\hline
\end{tabular}

Source: Own elaboration.

The subject matter of taxation is about its effects, both in terms of welfare and the competitive position of the industry. For the tourist industry, the argument is not about paying the normal tax regime for the provision of goods and services within a jurisdiction but rather additional discriminatory taxes. Too put it simply the industry does have a view that politicians 'heap' taxes on foreign tourists because they do not constitute their voters. There is no doubt that more research is required on what precisely comprise environmental taxes and subsidies that have a bearing on destinations and whether they can be applied optimally. 
Articles on the organisation of tourism are inevitably correlated with those concerning tourism marketing and policy, which deal with the rationale for government intervention, such as regional development, the 'infant industry' argument, guardianship of the resource base, and mechanisms for intercession. These in turn tie into more recent papers to do with crisis management, where tourism organisations in this century have found themselves wanting in having strategies to deal with a string of natural disaster and terrorist activity. An analytical slant has been to consider such events within the framework of chaos theory.

\section{MACRO ASSESSMENT}

As might be imagined, destinations studies, as shown in Table 9, are a popular area for economists to apply their talents, and destination management, marketing and the creation of partnerships to deliver local tourism strategies are very much in vogue. Submissions to Tourism Economics run the gambit from winter/ summer/ coastal/rural/urban to more specific locations such as lakes and mountains. This connects neatly into development aspects, for example, why destinations rise and fall, and the use of modern growth theory to examine both the causality and the contribution of tourism to economic growth. A feature of this is destination carry capacity, but this has attracted little research from economists.

Table 10

Macro Assessment

\begin{tabular}{|l|c|}
\hline \multicolumn{1}{|c|}{ SUBJECT } & $\mathbf{1 9 9 5 - 2 0 1 1}$ \\
\hline Destinations & $28 \%$ \\
\hline Impact Effects & $24 \%$ \\
\hline Growth and Development & $29 \%$ \\
\hline Sustainability & $13 \%$ \\
\hline International Trade & $6 \%$ \\
\hline
\end{tabular}

Source: Own elaboration.

Much research has gone into measuring the impact effects of Keynesian income and employment multipliers, whose values will be greater: the greater the value added; the more inputs are locally sourced; and the lower the import content of goods and services consumed on account of tourist spending. Many of the models are based on input-output (I-O) tables (Leontief, 1986) using fixed price assumptions, which are considered to have validity at the local level. For the economy at large, computable general equilibrium (CGE) models are 
now being used as they can embody flexible price assumptions (Ginsburgh and Keyzer, 1997). CGE models include more general specifications of the behaviour of consumers, producers and investors, than allowed in I-O models, thus permitting specific models to be calibrated to actual conditions in a specific economy, depending on data availability. They have a high degree of empirical content in the form of detailed commodity flows, labour market data and national accounts statistics. I-O models identify leakages of spending that limit multiplier effects with recognition that economy wide effects should be taken into account. CGE takes the view that an expanding industry, given factor constraints, may crowd out other sectors of economic activity, thus being more likely to generate price as well as quantity adjustments.

As regards development matters, considerable interest has been given to examining the causal relationship between tourism and economic growth. For island economies submissions have also explored the phenomenon of the 'Dutch disease', where strong tourism exports have an inflationary effect, that makes other export sectors in the local economy uncompetitive, thus exposing the economy to increasing risk arising from fluctuations in foreign markets. While authors have been very industrious in producing quantitative analysis, it should not be forgotten that for successful tourism development international agencies now recognise a tripartite approach to policy that takes into account economic, social and environmental factors: what has been called the 'triple bottom line'. This is where cost-benefit analysis at project level differs extensively from impact models such as CGE, since the focus of the latter is almost solely on the change in economic activity. Increasing attention is being given to balancing the 'triple bottom line' so as to encompass responsible and pro-poor tourism, in order to promote conservation and equity amongst different generations.

It will be appreciated that the literature on sustainability is extensive. The effect of market failure on the pursuit of sustainability entails the 'public goods' significance of many tourism resources, in respect of externalities that degrade natural and man-made environments. To economists this is about optimal economic development paths subject to constraints, wherein journal contributions have been about developing measurable indicators and eco-policies. The current emphasis has been on carbon footprints and waste generation. One of the inconveniences here is that sustainability is bedevilled by a lack of secondary data on which research can be based due governments being loath to spend money on collecting additional statistics. Much existing data is both ambiguous and poor in recognising changes deemed important to sustainability.

International trade in tourism flows is an area where there are opportunities for more research. The Ricardian and Heckscher-Ohlin theories do not pay sufficient attention to the managerial aspects of the visitor economy, in terms 
investment in modern infrastructure, marketing strategies by sellers to position themselves, such as branding, and the more eclectic theories of Linder(1961) and Porter(1990, 1998) that relate to market structures and emphasize interindustry trade: explaining trade in services and tourism as a consequence of both similarities and dissimilarities of tastes. These models emphasise the role of intra-industry trade based on imperfect competition, product differentiation and scale economies. There are empirical measures to look at this, for example, the Balassa index of revealed comparative advantage (1965) and the GrubelLloyd index (1975). This is an important area for tourism research that is connected to the 'triple bottom line' when tourism involves travel to remote areas where the divergence between the culture of the foreign tourist and the local community is often vast and where the argument is for a greater care of the natural environment. It requires strategies that are pro-poor yet minimise the impacts of the 'acids of modernity' on the lives of residents.

\section{CONCLUSIONS}

Research in tourism draws on a range of academic disciplines that leads to tourism being defined by a domain of different studies. From the perspective of governments, interest lies very much in the business aspects, particularly job creation, and tourism economists, as witnessed here by the diversity of papers sent to Tourism Economics, have been very capable of adapting their analytical and quantitative skills to exploring the many facets of the tourism industry.

It is commonly said that 'application without theory is blind, whereas theory without application is sterile'. This sums up the philosophy of the journal as a study in applied economics for bettering the tourism experience, government policy and business operations. The breakdown of the extent of submissions by the various subject areas, as illustrated in Table 1 and Tables 4-10, give an indication of topics requiring further exploration. In view of the quantitative nature of much of the research, a major hindrance to progress in many areas has been the lack of secondary data, forcing researchers to collect primary data, which is time consuming and often complex in its gathering, notably in respect of confidentiality. On the positive side, as the profile of tourism rises in importance as an economic activity, more resources are being devoted by governments to collecting information.

\section{REFERENCES}

BALASSA, B. (1965). "Trade liberalisation and revealed comparative advantage". The Manchester School of Economic and Social Studies, 33, 99-123. 
BAUMOL, W., J. PANZAR AND R. WILLIG (1982). Contestable Markets and the Theory of Industrial Structure. New York: Harcourt Brace Jovanovich.

CHARNES, A., W. COOPER AND E. RHODES (1978). "Measuring the efficiency of decision making units". European Journal of Operational Research, 2, 429-444.

DWYER, L., P. FORSYTH, AND W. DWYER (2010). Tourism Economics and Policy. London: Channel View Publications.

FARRELL, M. (1957). "The measurement of productive efficiency". Journal of Royal Statistical Society, A series, 120, 253-281.

GRUBEL, H. AND P. LLOYD. (1975). Intra-Industry Trade. The theory and Measurement of International Trade in Differentiated Products. London: Macmillan.

LANCASTER, K. (1966). "A new approach to consumer theory". Journal of Political Economy, 84, 132-157.

LINDER, S. (1961). An Essay on Trade and Transformation. London: John Hopkins.

MARTIN, S. (1993). Advanced Industrial Economics. Cambridge MA: Basil Blackwell

PORTER, M. (1990). The Competitive Advantage of Nations. New York: Free Press.

PORTER, M. (1998). Competitive Strategy: Techniques for Analysing Industries and Competitors: With a New Introduction. New York: Free Press.

STABLER, M., A. PAPATHEODOROU AND M. SINCLAIR (2010). The Economics of Tourism. London: Routledge.

UN WORLD TOURISM ORGANISATION (1999). Tourism Satellite Account (TSA): The Conceptual Framework. Madrid: UNWTO.

LEONTIEF, W. (1986). Input-Output Economics. New York: Oxford University Press.

GINSBURGH, V. AND M. KEYZER (1997). The Structure of Applied General Equilibrium Models. Cambridge MA: MIT Press. 